\title{
IDENTIFICATION, INSECTICIDAL EFFECT AND ANTIBIOSIS STUDIES OF SOME BACTERIA CHECKED ISOLATED FROM NATURALLY INFECTED Pectinophora gossypiella (SAUND.) COLLECTED FROM COTTON FIELDS IN EGYPT. \\ Abou-zeid N. M. 1; Kreema A. El-Lebody ${ }^{2}$; Noher A. Mahmoud ${ }^{1}$ and Manal A. EISharkawy ${ }^{2}$ \\ 1. Microorganisms unit, Plant Pathology Research Institute, Agriculture Research Centre Giza Egypt. \\ 2. Bollworm Research Division, Plant Protection Institute, Agriculture Research Centre, Giza, Egypt.
}

\begin{abstract}
One of the important Integrated Pest Management Strategies (IPM) against economic pests in Egypt is the use of biological control methods. The use of entomo pathogenic bacteria is one of these methods. The authors achieved four isolates of bacteria from the naturally infected $P$. gossypiella in cotton fields at Assuit and Kafr El-Sheikh Governorates, Egypt. Isolates were characterized based on morphological properties. Morphological analyses were carried out based on Bergey's Manual of Systematic Bacteriology. The identification of the isolated bacteria was confirmed by using Biolog-System as, Staphyloccus sciuri, Micrococcus luteus, Brevibacterium lines \& Brevibacterium casei. In addition, their larvicidal effect was evaluated. The results revealed that, $S$. sciuri and $M$. luteus were the most effective against $1^{\text {st }}$ instar larvae of PBW. Furthermore, their latent effect caused the lowest pupation \% resulted from treated PBW larvae. S. sciuri was the most promising bacterial isolate to be developed as a biological control agent against $P$.gossypiella.

The antagonists of bacterial strain against the mycelial growth of the pathogenic fungi (Rhizoctonia solani, Fusarium solani and Macrophomia phaseolina), was experimently tested to evaluate growth reduction of all pathogenic fungi.

Keywords:_Pink Bollworm, PBW, Pectinophora gossypiella, Identification, Insecticide effect, Antibiosis isolated bacteria, Staphyloccus sciuri, Microc occus luteus, Brevibacterium lines, fungi, Brevibacterium casei (Rhizoctonia solani, Fusarium solani, Macrophomia phaseolina).
\end{abstract}

\section{INTRODUCTION}

Pectinophora gossypiella (Saund.) (Gelchiidae: Lepidoptera) is worldwide distributed and considered one of the serious pests of cotton. Although, various cultural, chemical and biological methods are being used to control this pest, its damage still continues effectively all over the world.

However, the use of biological control methods offers a plentitude of approaches for a highly selective and environmentally sound control of insect pests. These include the application of beneficial arthropods, entomopathogenic, micro-organisms (including fungi, bacteria and viruses), and natural substances and botanicals for pest control. And they are of great importance for Integrated Pest Management Strategies (IPM) (Johannes, 2013). In this regard, many investigation were carried out to isolate 
entomopathogenic bacteria from either healthy or moribund insect pests e.g., Brevibacterium lines and Staphyloccus sciuri have been isolated from health Xylosandrus germanus (Blandford) (Coleoptera: Curculionidae) collected in hazelnut orchards in Turkey (Ahmet and Hatice, 2013).While, Micrococcus luteus isolated from Euproctis chrysorrhoea L. (Lepidoptera: Lymantriidae) as well as from Asian live longhorned beetle, Anaplophora glabripennis (Motschulsky), larvae and adults (Mustafa et al., 2000 and John et al., 2013). Ahmet and Hatice (2013) reported that, several species of bacterial isolates related to genera Brevibacterium \&Staphyloccus and others are used in biological control as an antifungal and insecticidal against agricultural pests.

Also, the study on the bacterial community of PBW may give a better chance to find significant microbial control agent against this pest. In this regard, many bacterial strains representing several genera were isolated from infected active and / or resting PBW larvae (Abul-Nasr et al., 1978; Khoja et al., 2006 and Reda et al., 2013). Furthermore, the symbiont, Enterobacter gergoviae, isolated from the gut of the pink bollworm (PBW), has been transformed to express Cyt1A, a cytolytic protein toxin lethal to mosquito and black fly larvae, as a model system. These transgenic bacteria might be used to spread genes encoding insecticidal proteins to populations of agricultural insects or as replacement for chemical insecticides (Lyudmila et al., 2002).

The present study aimed to isolate, identify and determine the potency of virulent bacteria of infected $P$. gossypiella larvae. The study was extended to investigate the effect of these isolates on the immature stages of PBW resulted from treated newly hatched larvae and try to find a safe bio-control agent against this pest in IPM program.

\section{MATERIALS AND METHODS}

\section{Obtaining of the infected PBW larvae:}

Healthy PBW full grown larvae were excluded from green cotton bolls collected from various locations of Kafr El-sheikh and Assiuat Governorates, Egypt during season 2014. The larvae were kept individually into sterilized glass tubes $(2 \times 7 \mathrm{~cm})$ capped by cotton wool to prevent any contamination, and incubated under room conditions. These larvae were examined weekly. The sick larvae which show symptoms of entomopathogenic bacterial infection were separated and examined daily. As soon as the death of moribund larvae (Fig1-4) they were kept in a refrigerator at $5{ }^{\circ} \mathrm{C}$ until isolation of bacterial community of PBW larvae.

Isolation and identification of bacteria of infected PBW larvae:

The plate count method was used for isolation and identification of bacteria from dead PBW larvae using various assays (Ahmet and Hatice 2013). The surface of larvae specimens were sterilized with $70 \%$ ethanol (Pidiyar et al., 2004) in a sterile hood. The sick larvae were homogenized in $9 \mathrm{ml}$ of sterile distilled water by using a glass tissue grinder.

Serial dilutions from $10^{-1}$ to $10^{-6}$ were prepared from the suspension by using sterile distilled water as dilution to study the microorganisms. One $\mathrm{ml}$ of both dilutions $\left(10^{-4}\right.$ and $\left.10^{-6}\right)$ were used for the isolation of bacteria on Petri 
plates containing nutrient agar medium (Thomas et al., 2012), for isolation of bacteria $0.1 \mathrm{ml}$ of each desired dilution was placed and streaked on the surface of each plate using special sterile glass rod. The plates were incubated at $\left(28 \pm 2{ }^{\circ} \mathrm{C}\right)$ and $\left(37 \pm 2{ }^{\circ} \mathrm{C}\right)$ for $2-7$ days until developing of single colonies. Different separated bacterial colonies were picked up, then transferred on a new medium, and re-incubated again.

The bacterial isolates were purified by employing single colony isolation. Bacteria strains were purified by using the streak technique and selected based on their colors and colony morphologies. Morphological analyses were carried based on Bergey's Manual of Systematic Bacteriology (Schreckenberger et al., 2007 and Logan et al., 2009).

The resulted bacterial isolates were maintained on nutrient agar and PDA slant media, respectively and kept in a refrigerator at $5{ }^{\circ} \mathrm{C}$ till achieving identification. The identification of the isolated micro-organisms was confirmed by using Biolog-System technique which belonged to identification of microorganisms unit, Plant Pathology Research Institute, A.R.C., Giza, to differentiation between them by using of carbon and amino acid compounds.

Larvicidal effects of bacterial isolates against $\boldsymbol{P}$. gossypiella:

Insect used:

Newly hatched larvae of $P$. gossypiella were obtained from a colony maintained in the laboratory for several generations at $\left(27 \pm 1^{\circ} \mathrm{C}\right.$ and $75 \pm 5 \%$ R.H). Larvae were reared on a modified artificial diet as described previously by Rashad and Amar, (1985).

\section{larvicidal studies:}

The stock suspension of 4 bacterial isolates (contain $1 \times 10^{8}$ spore $/ \mathrm{ml}$ ) related to three genera of bacteria recorded for the first time associated with $P$. gossypiella, were evaluated against newly hatched larvae of PBW as follows: a volume of each suspension of each bacterial isolate was homogeneity mixed with artificial diet (without the antimicrobial agents) to obtain the tested concentration $\left(1 \times 10^{8} \mathrm{spore} / \mathrm{ml} / 1 \mathrm{gm}\right.$ diet / isolated bacterium). After preparation of treatments, each one was individually folded into 4 Petri dishes $(9 \mathrm{~cm}$ in diameter). Fifty neonate larvae of pink bollworm susceptible laboratory strain were added to each Petri-dish. A control experiment was done, but Petri-dishes were prepared with diet mixed with double distilled water. Larvae of all treatments were allowed to feed on the treated diet for one day then alive larvae were transferred individually to glass tubes $(2 \times 7 \mathrm{~cm})$ containing untreated artificial diet. Tubes were plugged with cotton wool and incubated at $\left(26 \pm 1^{\circ} \mathrm{C}\right.$ and $70 \pm 5 \%$ R.H). Percentages of mortalities of $1^{\text {st }}$ and $4^{\text {th }}$ larval instars were estimated.

In vitro Antibiosis Studies

An antagonistic effect of Bacterial isolates (Brevibacterium lines, Staphyloccus sciuri, Micrococcus luteus and. Brevibacterium casei), were tested against different pathogenic fungi (Rhizoctonia solani, Fusarium solani and Macrophomia phaseolina), isolated from rotted cotton using PDA medium. 
Disks (5mm-diam.) taken from seven day old culture of pathogenic fungi, were transferred onto potato dextrose agar PDA plates $(9 \mathrm{~cm})$. The antagonistic tested bacteria were individually streaked in opposite direction of the pathogenic fungi. Three Petridishes were used for each isolate and the same number was kept as control with pathogen alone. The inoculated plates were incubated at $\left(26-28^{\circ} \mathrm{C}\right)$ until the growth completely covered the plate surface in control treatment.

The interaction between pathogenic fungi and bacteria isolates were recorded to determine the more effective antagonistic isolates. The reduction percent in mycelia growth of pathogenic fungi was calculated using the formula as follows:

$$
\text { Reduction } \%=\frac{\mathrm{C}-\mathrm{T}}{\mathrm{C}} \times 100
$$

Where:

$\mathrm{C}=$ fungal growth of pathogenic fungi in control treatment.

$\mathrm{T}=$ fungal growth of pathogenic fungi in presence of antagonis.

\section{RESULTS AND DISCUSSION}

The authors achieved four isolates of Bacteria from the infested $P$. gossypiella larvae related to three genera of bacteria. Photography was taken for deseased larvae of each bacterium which die due to the infection(Figs. 1$4)$; as well as healthy one (Fig.A). Isolates were characterized based on morphological properties. Morphological analyses were carried out based on Bergey's Manual of Systematic Bacteriology. The identification of the isolated bacteria was confirmed by using Biolog-System as, Staphyloccus sciuri (samples of Assuit), Micrococcus luteus, Brevibacterium lines, and. Brevibacterium casei. In addition, the larvicidal potency of these bacterial isolates was determined against $P$. gossypiella larvae.

In present study, the isolated bacteria from $P$. gossypiella were found to be different from previous studies performed by Abul-Nasr et al. (1978); Khoja et al., (2006) and Reda et al. (2013). They isolated 13 bacteria from P.gossypiella, including, Bacillus thuringiensis, B. $t$. var. thuringiensis, $B$. $t$. var. finitimus, B. cereus, B. polymyxa, B. subtilis, Cellulomonas flavigen, Pseudomonas viridiflava, P. pyrrocinia, $P$. aeruginosa, Serratia grimesii, Serratia marcescens and $S$. rubidaea. The probability for this difference is conceptualizes to the geographical local position.

On the other hand, the bacteria isolated recently from $P$. gossypiella had been isolated from various insect species before. In this regard, entomopathogenic bacteria were isolated from either healthy or moribund insect pests e.g., Brevibacterium lines, Brevibacterium casei and Staphyloccus sciuri had been isolated from health Xylosandrus germanus (Blandford) (Coleoptera: Curculionidae) collected in hazelnut orchards in Turkey (Ahmet and Hatice ,2013).While, Micrococcus luteus isolated from Euproctis chrysorrhoea L. (Lepidoptera: Lymantriidae) as well as from Asian 
live longhorned beetle, Anaplophora glabripennis (Motschulsky), larvae and adults (Mustafa et al.,2000 \& John et al.,2013).

Larvaicidal effects of Isolates:

These isolates were evaluated against $1^{\text {st }}$ and $4^{\text {th }}$ instars larvae of PBW as well as their latent effects on larval stage and pupation \% under laboratory conditions.

Data in Table (1) indicated that the mortality \% obtained from all isolates ranged between (22\% to $67.3 \%$ ) against the treated PBW $1^{\text {st }}$ instar larvae within 2 days after application of $1 \times 10^{8} \mathrm{cfu} / \mathrm{mL}$ bacterial concentration at $27^{\circ} \mathrm{C}$ under the laboratory conditions. While, the accumulated percent mortalities in $4^{\text {th }}$ instar larvae were $(31 \%$ to $88.7 \%)$. In comparison the mortality $\%$ in control were $4 \%$ and $6 \%$ of $1^{\text {st }}$ and $4^{\text {th }}$ instars larvae, respectively. In addition, the obtained accumulated mortality of larvae from all treatments ranged between (47 to 90\%). The corresponding accumulated mortality in control was $8 \%$. In sequence the pupation $\%$ of all treatments ranged between $(10 \%-53 \%)$ compared to $92 \%$ in the control. Present findings indicate that these bacterial isolates appear to be a good candidate to be utilized as promising biocontrol agents for use against PBW $P$. gossypiella. In this regard, Ahmet and Hatice (2013), reported that, several species of bacterial isolates related to genera Brevibacterium and Staphyloccus and others are used in biological control as an antifungal and insecticidal against agricultural pests.

Table (1): Effect of isolates against treated P.gossypiella.

\begin{tabular}{|c|c|c|c|c|c|c|}
\hline \multirow{2}{*}{ Instar / stage } & \multirow{2}{*}{$\begin{array}{c}\text { Days } \\
\text { after } \\
\text { treatment }\end{array}$} & \multicolumn{5}{|c|}{ Mortaltiy $\%$ in control and treated PBW } \\
\hline & & control & $\begin{array}{c}\text { Staphyloccus } \\
\text { sciuri }\end{array}$ & $\begin{array}{c}\text { Micrococcus } \\
\text { luteus }\end{array}$ & $\begin{array}{c}\text { Brevibacterium } \\
\text { lines }\end{array}$ & $\begin{array}{c}\text { Brevibacterium } \\
\text { casei }\end{array}$ \\
\hline $1^{\text {st }}$ instar & 2 & 4 & 67.3 & 45 & 22 & 23.4 \\
\hline $4^{\text {th }}$ instar & 11 & 6 & 88.7 & 74 & 31 & 39 \\
\hline Larval stage & 21 & 8 & 90 & 84 & 80 & 47 \\
\hline \multicolumn{7}{|c|}{ Pupation \% } \\
\hline Pupal stage & 21 & 92 & 10 & 16 & 20 & 53 \\
\hline
\end{tabular}

In this respect, this results demonstrating that Brevibacterium lines, Staphyloccus sciuri; Micrococcus luteus and Brevibacterium casei are recorded for the first time as pathogenic to $P$. gossypiella is considered the first record.

\section{Comparison of the insecticidal effects of isolates against PBW:}

\section{1-Staphylococcus sciuri:}

The body of naturally infected PBW larvae with Staphylococcus sciuri is shrunk with dark brown color (Fig.1). In this respect, Abul-Nasr et.al (1978) found that two pathogenic bacterial strains, Bacillus thuringiensis var. finitimus and $B$. cereus, were isolated from sick or dead resting larvae of $P$. gossypiella carrying dermal brown lesions. 


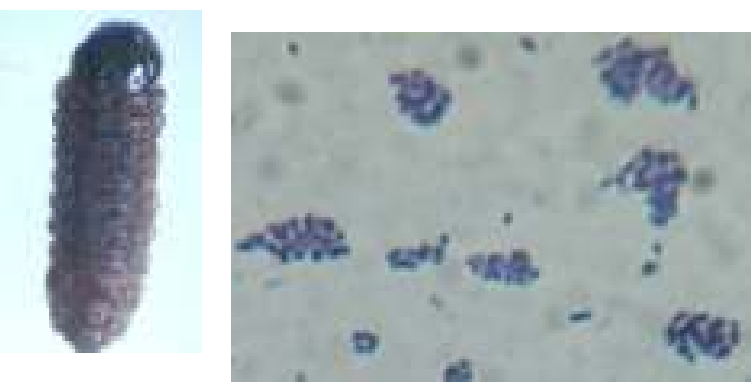

Figure (1): Naturally infected PBW with Staphylococcus sciuri

As shown in Table (1) Staphyloccus sciuri caused the highest mortality $\%(67.3 \%) \&(90 \%)$ either in PBW $1^{\text {st }}$ larval instar or in all larval stage (accumulated larval mortality). Also, it caused the lowest percent of PBW pupation (10\%). Upon, these results Staphyloccus sciuri is considered the most effective against PBW because it achieved the control of protective type. However, Ardahan et al. (2013) reported that, Staphylococcus species is one of the most well-known bacterial pathogens of insects. Furthermore, Pascal et al. (2011) found that, Staphylococcus sciuri, acts as a kairomone enhancing the efficiency of aphid natural enemies.

On other hand, Hauschild and Schwarz (2003) indicated that, Twentynine Staphylococcus sciuri strains were isolated from free-living insectivores and rodents. Also, Staphylococcus sciuri may be human pathogen. Jerry et al. (2010) reported that, Staphylococcus sciuri has been associated mostly with wound infections although it can be isolated from other infections such as urinary tract infections and endocarditic.

In conclusion, Staphyloccus sciuri may have potential for future development as microbial control agents against $P$. gossypiella, but, the healthy alerts and indications must be followed at the use of this bacterium.

2-Micrococcus luteus:

As shown in Fig. (2) the infected PBW with this bacterium exhibited following symptoms:

The color of dead PBW body did not significantly differ from that of the healthy larvae. The whole body was soft and the internal organs were broken down and liquefied.

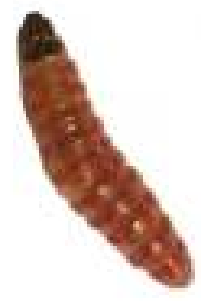

Figure (A): Healthy PBW larvae 

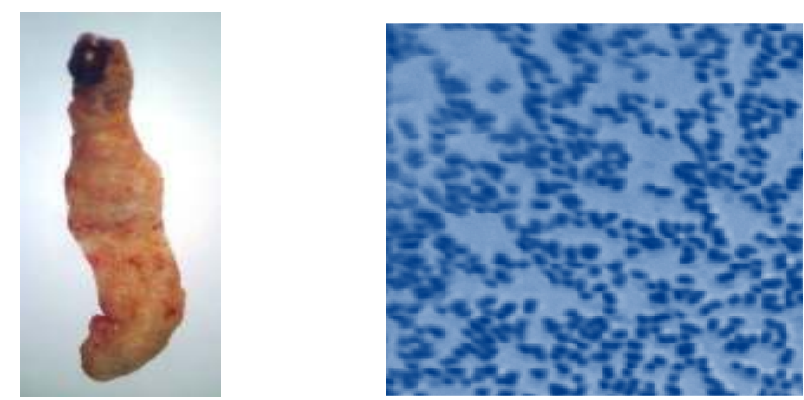

Figure (2): Naturally infected PBW with Micrococcus luteus

This isolate got the second position of efficiency against $P$. gossypiella.It caused $45 \%, 74 \% \& 84 \%$ mortality in the $1^{\text {st }}$ and $4^{\text {th }}$ larval instars and the whole larval stage. Only $16 \%$ of PBW larvae reached the pupal stage. The present study indicates that, this isolate appears to be a good bio - control agent against $P$. gossypiella. While, Mustafa et al. (2000) isolated Micrococcus luteus from Euproctis chrysorrhoea L. (Lepidoptera: Lymantriidae) and found that, the insecticidal effect \% of this isolate is $15 \%$ against Euproctis chrysorrhoea L. However, Micrococcus luteus (Schroeter) can be a nosocomial human pathogen (Peces et al. 1997 (c.f. John et al.,2013))

\section{3-Brevibacterium linens and Brevibacterim casei:}

The infected PBW with Brevibacterium linens appears cureved with yellow thorax and dark brown body. Also, there was a yellow liquid under the abdomen portion (Fig3).While, the Brevibacterim casei infection caused infelation of abdomen and the body color became light brown. (Fig.4)

Both of Brevibacterium linens (samples of Assuit) and Brevibacterim casei (samples of Kafr El- sheik) are not effective against $P$. gossypiella. They caused $(22 \% \& 23.4 \%)$ and $(31 \% \& 39 \%)$ mortality in the $1^{\text {st }}$ and $4^{\text {th }}$ larval instars, respectively. In contrary, Brevibacterium linens was more effective $(80 \%)$ against the larval stage where only $20 \%$ of treated larvae reach pupal stage. The corresponding latent insecticidal effects of Brevibacterim casei were $47 \%$ and $53 \%$, in larval and pupal stages, respectively.

However, Homopteran insects contain bacteria in their cells and tissues known as "secondary symbionts," Brevibacterim casei which under special environmental circumstances act against their host insects (Mazen et al., 2010). But, Ahmet and Hatice (2013) reported that, several species of bacterial isolates related to genera 

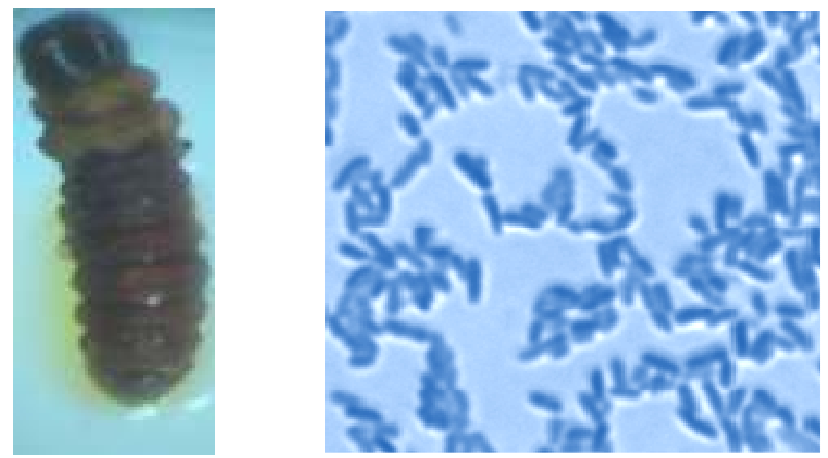

Figure (3): Naturally infected PBW with Brevibacterium linens
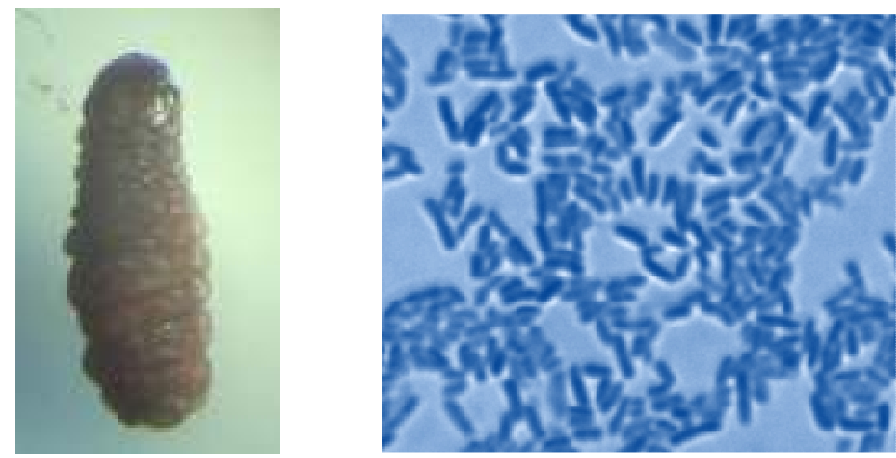

Figure (4): Naturally infected PBW with Brevibacterium casei

Brevibacterium and others are used in biological control as an antifungal and insecticidal against agricultural pest. Because of the weakness effect of Brevibacterium linens and Brevibacterim casei against the $1^{\text {st }}$ instar of $P$. gossypiella, makes it worse in control of this pest.

The present study concluded that, Staphyloccus sciuri and Micrococcus luteus isolates may have potential for future development as microbial control agents against $P$. gossypiella. But, the healthy alerts and indications must be followed at the use of these bacteria. Also, further studies should include field efficacy of these isolates.

Antibiosis studies in vitro

The antagonistic effect of bacterial isolates on the growth of pathogenic fungi :

This experiment was carried out to evaluate the effect of different antagonistic bacterial strains (Brevibacterium lines, Staphyloccus sciuri, Micrococcus luteus and Brevibacterium casei), against the mycelial growth of the pathogenic fungi (Rhizoctonia solani, Fusarium solani and Macrophomia phaseolina), isolated from rotted cotton.

Results in Table (2) indicated that the tested antagonist's strains show no difference between them in their antagonistic activity against all of the 
tested pathogenic fungi .The growth reduction recorded $0.0 \%$ of both fungi as the control.

Table (2): The antagonistic effect of 4 bacterial strains against three pathogenic fungi (Rhizoctonia solani, Fusarium solani and Macrophomia phaseolina), In vitro.

\begin{tabular}{|l|c|c|c|c|c|c|}
\hline Bacterial isolates & \multicolumn{2}{|c|}{$\begin{array}{c}\text { Rhizoctonia } \\
\text { solani }\end{array}$} & \multicolumn{2}{c|}{$\begin{array}{c}\text { Fusarium } \\
\text { solani }\end{array}$} & \multicolumn{2}{c|}{$\begin{array}{c}\text { Macrophomia } \\
\text { phaseolina }\end{array}$} \\
\hline & $\begin{array}{c}\text { Linear } \\
\text { growth }\end{array}$ & $\begin{array}{c}\text { Reduction } \\
\%\end{array}$ & $\begin{array}{c}\text { Linear } \\
\text { growth }\end{array}$ & $\begin{array}{c}\text { Reduction } \\
\%\end{array}$ & $\begin{array}{c}\text { Linear } \\
\text { growth }\end{array}$ & $\begin{array}{c}\text { Reduction } \\
\%\end{array}$ \\
\hline Brevibacterium lines & 9.0 & 0.0 & 9.0 & 0.0 & 9.0 & 0.0 \\
\hline Staphyloccus sciuri & 9.0 & 0.0 & 9.0 & 0.0 & 9.0 & 0.0 \\
\hline Micrococcus luteus & 9.0 & 0.0 & 9.0 & 0.0 & 9.0 & 0.0 \\
\hline Brevibacterium casei & 9.0 & 0.0 & 9.0 & 0.0 & 9.0 & 0.0 \\
\hline Control & 9.0 & 0.0 & 9.0 & 0.0 & 9.0 & 0.0 \\
\hline
\end{tabular}

The antagonistic bacterial strains were no specific against all of the tested pathogenic fungi. These results are in harmony with the findings of Yuliar, et al (2013), where they verified the positive and the negative role of 14 bacterial strains in inhibition ability to both of $R$. solani and $F$. oxysporum growth in PDA media. The selected strains showed that their ability to suppress of $R$. solani growth were in range of $16-60 \%$ in PDA media. Five strains did not suppress $R$.solani.

Nine of the selected strains inhibited $F$. oxysporum growth in the range of $10-47 \%$ in PDA media and five strains did not suppress $F$. oxysporum in PDA media media.

Some possibilities of fungal pathogens suppression mechanisms by bio - control agent had been investigated by some author within series of action including antibiosis work (Souto et al.,2004; Yuliar et al., 2011); as lytic enzymes activities such as chitinases and proteases production (Huang et al.2005) ; competition of iron through the production of siderophore and caused the induction of systematic resistance and ability producing antibiosis of iturin and surfactin, as well as due to enzymatic chitinase action (De Boer et al., 2003).

Antibiosis mechanism could be due to their extracellular metabolites production excreted by endophytic bacteria which acted fungal cell membrane damage. In the laboratory test for antagonism through this observation, media used causing dissimilarity of positive and negative result of antagonism affect for some certain endophytic strain, while the quantity result differences also occur within the same strain. The range of inhibition ability in different media showed different effect to inhibition percentage. The result of the present study confirms previous reports of antibiotic polypeptide production by bio - control investigation had been worked by Shoda (2000) and Akpa et al. (2001). Also, Raaijmaker (2002) indicated that suppression of fungal pathogen $R$. solani and $F$. oxysporum by some certain endophytic bacterial strains are because of antibiosis production of bioactive iturin and surfactin, and also caused by chitinase enzyme production. 


\section{REFRENCES}

Abul-Nasr S. E., M. F. S. Tawfik, E. D. Ammar and S. M. Farrag (1978): Occurrence and causes of mortality among active and resting larvae of Pectinophora gossypiella (Lepidoptera, Gelechiidae) in Giza, Egypt. Zeitschrift für Angewandte Entomologie, Volume 86, Issue 1-4, pages 403-414.

Ahmet KATI and Hatice KATI (2013): Isolation and identification of bacteria from Xylosandrus germanus (Blandford) (Coleoptera: Curculionidae). African Journal of Microbiology Research, Vol. 7(47), pp. 5288-5299.

Akpa E., P. Jacques, B. Wathelet, M. Paquot, R. Fuchs, H. Budzikiewicz, and P. Thonart (2001): Influence of culture conditions on lipopeptide production by Bacillus subtilis. Applied Biochemical \& Biotechnology, 91-93:551-561.

Ardahan, E.; Mustafa G.; Filiz, O. Ç.; Zihni, D.; İsmail, D. (2013): Investigations on bacteria as a potential biological control agents on corn stalk borer, Sesamia nonagrioides (Lef.) (Lepidoptera: Noctuidae) $4^{\text {th }}$ International Participated Entomopathogens and Microbial Control Symposium 11-14 September 2013. Artvin, Turkey, Page 38.

De Boer, F. Kindt, Joost, J.B Keurentjes, I.van der Sluis, L.C.van Loon and P.H.A.M. Baker (2003): Control Fusarium wilt of radish by combining of Pseudomonas putida strains that have different diseases mechanisms. Phytopatology, 93(5):626-632.

Hauschild,T. and Schwarz S.(2003): Differentiation of Staphylococcus sciuri Strains Isolated from Free-Living Rodents and Insectivores. J. Vet. Med. B, 50: 241-246 (2003).

Huang C.J., T.K. Wang, S.C. Chung and C.Y. Chen (2005): Identification of an antifungal chitinase from a potential biocontrol agent, Bacillus cereus 28-9. Journal of Biochemistry and Molecular Biology, 38(1):8288.

Jerry F. B; Alejandra G.; Frank, M.; James E. M. (2010): Wild Florida house flies (Musca domestica) as carriers of pathogenic bacteria. Florida Entomologist 93(2) June 2010 218- 223

Johannes A. J. (2013): Biological Control of Pest Insects in Germany Presence and Future 4th International Participated Entomopathogens and Microbial Control Symposium 11-14 September 2013. Artvin, Turkey. Page, 20

John, D. P; Vincent D', A; Roger T. Z. and Heidi S. (2013): Bacteria associated with larvae and adults of the Asian Longhorned Beetle (Coleoptera: Cerambycidae) J. Entomol. Sci. 48(2): 128-138 (April2013).

Khoja, S. M.T.; Rezk, G. N.; Madiha, A. R.; Hanafy, H. E. M (2006): Identification and efficiency of bacterial strains isolated from infected larvae of cotton pink bollworm Pectinophora gossypiela and spiny bollworm Earias insulana (Lepidoptera: Noctuidae). Arab Universities Journal of Agricultural Sciences 2006, Vol. 14(20): 777-788. 
Logan, N.A., De Vos, P., Genus, I. (2009): In: De Vos, P., Garrity, G.M., Jones, D., Krieg, N.R., Ludwig, W., Rainey, F.A., Schleifer, K.H,. Whitman, W.B. (Eds.), Bacillus Cohn 1872, 174AL, 2nd edition. Bergey's Manual of Systematic Bacteriology, 3. Springer, New York, pp. 21-128.

Lyudmila,V. K; Erni D. M; Baoxue G. E; Thomas A. M. (2002): Transformation of Enterobacter gergoviae isolated from pink bollworm (Lepidoptera: Gelechiidae) gut with Bacillus thuringiensis toxin. Curr Microbiol. 2002 Jan; 44(1):1-4

Mazen A. A.; Mohamad, S; Mohammad, A. (2010): Isolation and identification of culturable forms of bacteria from the sweet potato whitefly Bemesia tabaci Genn. (Homoptera: Aleyrodidae) in Jordan Turk J. Agric. For 34 (2010):225-234.

Mustafa, Y; Zyhny D. and Ali, O. B. (2000): Isolation and insecticidal effects of some bacteria from Euproctis chrysorrhoea L. (Lepidoptera: Lymantriidae). Acta Microbiologica Polonica 2000, Vol. 49, No.3-4, 217-224.

Pascal D.L; Ahmed, S; Stephanie, H; Philippe T; Georges L; Francois, J.V; Frederic, F; Yves, B; Gary, W. F and Eric, H. (2011): Microorganisms from aphid honeydew attract and enhance the efficacy of natural enemies. Nature Communications Volume: 2, Article number: 348.

Peces, R., E. Gago, F. Tejada, A. S. Laures, J. A. (1997): Relapsing bacteraemia due to Micrococcus luteus in a haemodialysis patient with a Perm-Cath catheter. Nephrol. Dial. Transplant, 12: 2428-2429(c.f. John et al., 2013).

Pidiyar, V.J., Jangid, K., Patole, M.S., Shouche, Y.S. (2004): Studies on cultured and uncultured microbiota of wild Culex quinquefasciatus mosquito midgut based on 16s ribosomal RNA gene analysis. Am. J. Trop. Med. Hyg. 70: 597-603.

Raaijmakers , J. M., M. Vlami, and J. T. de Souza (2002): Antibiotic production by bacterial biocontrol agents. Antonie van Leeuwenhoek. 81:537-547.

Rashad, A.M. and Ammar, E.D. (1984): Mass rearing of the spiny bollworm, Eareas insulana (Biosd.) on semiartificial diet. Bull. Ent. Soc. Egypt, 65: 239-244.

Reda, F. M; Nada, M. A. and Abd-El- Azeem, E. M. (2013): Biological activity of some actinomycetal and bacterial isolates on certain aspects of the cotton pink bollworm, Pectinophora gossypiella (Saunders) (Lepidoptera: Gelechiidae). Egyptian Journal of Biological Pest control, Vol. 23 (2): pp. 261-267.

Schreckenberger, P.C., Daeshvar, M.I., Hollis, D.G. (2007): Acinetobacter, Achromobacter, Chryseobacterium, Moraxella, and other nonfermentative gram-negative rods. In: Murray, P.R., et al. (Eds.), Manual of Clinical Microbiology, 9 th ed. Am. Soc. Microbiol Washington, pp. 770-802.

Shoda, M. (2000): Bacterial control of plant disease. Journal of Bioscience and Bioengineering. 89(6): 515-521. 
Souto G.I., O.S. Correa, M.S. Montecchia, N. L. Kerber, N.L. Pucheu, M. Bachur and A.F. Garcia. (2004): Genetic and functional characterization of Bacillus sp., strain excreting surfactin and antifungal metabolites partially identified as iturin-like compounds. Journal of Apllied Microbiology, 97:1247-1256.

Thomas, P., Sekhar, A.C., Mujawar, M.M. (2012): Non recovery of varying proportions of viable bacteria during spread plating governed by the extent of spreader usage and proposal for an alternate spottingspreading approach to maximize the CFU. J. Appl. Microbiol. 113, 339350.

Yuliar, S., D. Supriyati and M. Rahmansyah (2013): Biodiversity of endophytic bacteria and their antagonistic activity to Rhizoctonia solani and Fusarium oxysporium. G.J.B.A.H.S., Vol. 2 (4): 111-118.

Yuliar, Z. Abidin and W. Mangunwardoyo (2011): Potency of Biocontrol Agents isolated from compost and peat soil of tropical swamp forest in Kalampangan zone, Central Kalimantan. Journal of Forestry Research, 8(2):

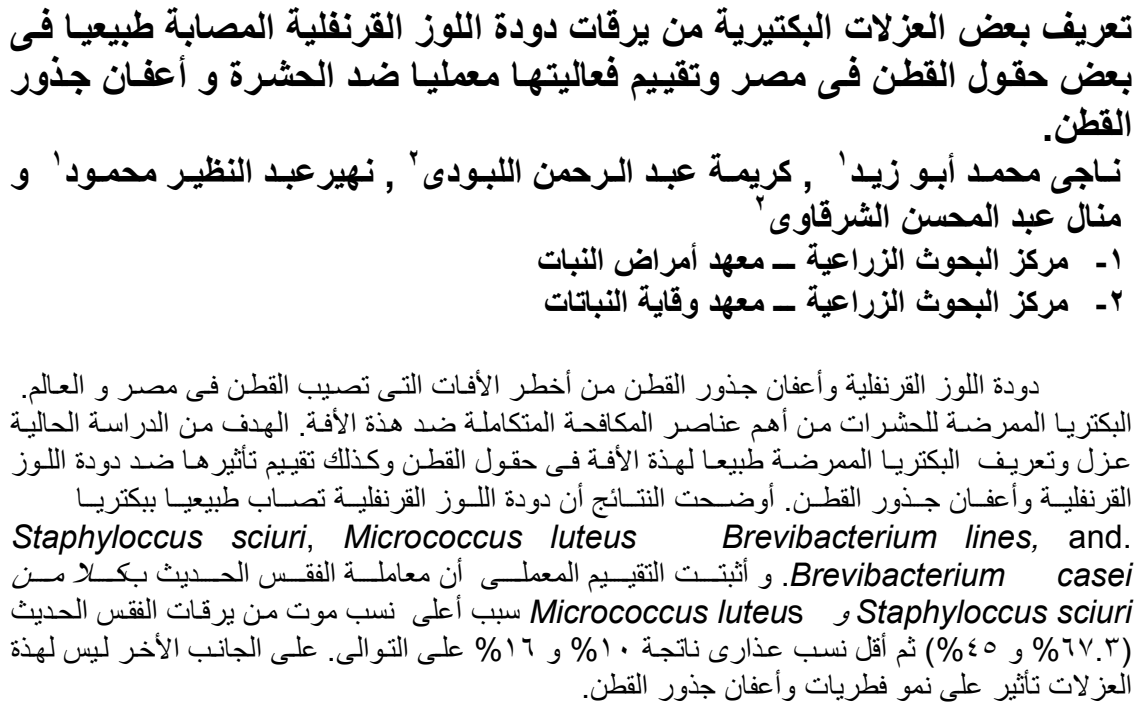

